\title{
Training the Modern Manager in the Context of the Competence Approach
}

\section{Capacitación del gerente moderno en el contexto del enfoque de competencia}

Dmitrichenkova S.V.*

RUDN University, Russia

ORCID: https://orcid.org/0000-0002-5001-7463

Stanchuliak T.G.

RUDN University, Russia

ORCID: https://orcid.org/0000-0002-9773-5438

Budiltseva M.B.

RUDN University, Russia

ORCID: https://orcid.org/0000-0002-5928-3362

\section{Bereznyakovsky V.S.}

K.G. Razumovsky Moscow State University of Technologies and Management, Russia ORCID: https://orcid.org/0000-0002-0890-1036

Orlova I.K.

K.G. Razumovsky Moscow State University of Technologies and Management, Russia ORCID: https://orcid.org/0000-0003-2245-2596

Filippova O.A.

K.G. Razumovsky Moscow State University of Technologies and Management, Russia ORCID: https://orcid.org/0000-0001-6314-9599

\section{Moiseeva O.A.}

K.G. Razumovsky Moscow State University of Technologies and Management, Russia ORCID: https://orcid.org/0000-0003-2239-1965

Received 01-11-20 Revised 02-25-20 Accepted 06-20-20 On line 07-30-20

*Correspondence

Email: rector@rudn.ru
Cite as:

Dmitrichenkova, S.V., Stanchuliak, T.G., Budiltseva, M.B., Bereznyakovsky, V.S., Orlova, I.K., Filippova, O.A., Moiseeva, O.A. (2020). Training the Modern Manager in the Context of the Competence Approach. Propósitos y Representaciones, 8 (SPE2), e632. Doi: http://dx.doi.org/10.20511/pyr2020.v8nSPE2.632 


\section{Summary}

The difficulties which the Russian Federation is facing in the social and economic spheres are connected with its integration into the world context, strengthened positions of the market economy, the perfection of the system of secondary and higher professional education, the innovative approach to training pedagogical specialists. Besides, the situation in the country facilitates the perception of managerial education as a constituent of global personal learning in the conditions of professional education whose main backbone is the manager able to meet the requirements of the new economic reality. Some experts forecast a specific "managerial revolution", which, as they say, will occur in the nearest future and become one of the reasons for our country to overcome the economic stagnation. It is suggested that "the human factor" and raising the qualification of managers will become key directions of Russia's social and economic development. Nowadays, providing the labor sector with managers of the new type, i.e. mobile, economically-minded, able to achieve good results in their profession due to the advanced level of their innovative entrepreneurial competence (IEC), is a complex task which is facing the secondary and higher professional education. In order to solve it, the government pays special attention to training specialists in the field of management, which is implied by official requirements to the content of the educational process presented in the most important federal documents: The Law About Education in the Russian Federation; The National Doctrine of Russian Education Development (till 2025) and others.

Keywords: Managerial Training; Modern Manager; Pedagogical Experiment; Competence Levels.

\section{Resumen}

Las dificultades a las que se enfrenta la Federación de Rusia en los ámbitos social y económico están relacionadas con su integración en el contexto mundial, el fortalecimiento de las posiciones de la economía de mercado, la perfección del sistema de educación profesional secundaria y superior, el enfoque innovador para la formación de especialistas pedagógicos. . Además, la situación en el país facilita la percepción de la educación gerencial como un componente del aprendizaje personal global en las condiciones de la educación profesional cuya columna vertebral principal es el gerente capaz de cumplir con los requisitos de la nueva realidad económica. Algunos expertos pronostican una "revolución empresarial" específica que, como dicen, ocurrirá en el futuro más cercano y se convertirá en una de las razones para que nuestro país supere el estancamiento económico. Se sugiere que "el factor humano" y elevar la calificación de los gerentes se convertirán en direcciones clave del desarrollo social y económico de Rusia. Hoy en día, proporcionar al sector laboral gerentes del nuevo tipo, es decir, móviles, de mentalidad económica, capaces de lograr buenos resultados en su profesión debido al nivel avanzado de su competencia empresarial innovadora (IEC), es una tarea compleja que enfrenta el Educación profesional secundaria y superior. Para resolverlo, el gobierno presta especial atención a la capacitación de especialistas en el campo de la gestión, lo cual está implícito en los requisitos oficiales del contenido del proceso educativo presentado en los documentos federales más importantes: La Ley de Educación en la Federación de Rusia; La Doctrina Nacional del Desarrollo Educativo Ruso (hasta 2025) y otros.

Palabras clave: Entrenamiento gerencial; Gerente moderno; Experimento pedagógico; Niveles de competencia

\section{Introduction}

The state and society create an increased demand for qualified specialists in the field of management, able to creatively fulfill their direct responsibilities as managerial subjects, to solve conflicts and other problems quickly and effectively, with innovative methods focused on the development of entrepreneurial activity being used. In this connection, the modern manager needs 
such personal and professional qualities as enterprise, mobility, the ability to see the reality from the point of view of innovative perspectives, the aspiration for continuous development of their potential within their specialty, the generation of progressive business solutions. All the characteristics make a competitive manager who is wanted in the conditions of the market economy (Badakhova, 2017; Narkevich, 2018; Borisova et al., 2018; Komarova, 2018; Sergeeva \& Trubakova, 2017; Schwarzkopf, 2018; Ashmarov, 2018; Badakhova, 2017; Gadzhieva, 2018).

Nowadays, the manager's activity, which greatly determines the company performance, implies numerous and diverse managerial functions. They are an integral part of innovative entrepreneurial activity in making a rational choice based on solid economic knowledge and skills, which facilitate troubleshooting.

Management is one or the other form has existed in every nook and corner of the world since the dawn of civilization. Modern Management has grown with the growth of socialeconomics and scientific institution. Modern view consists that a worker does not work for only money. They work for their satisfaction and happiness with good living style. Here Non- financial award is most important factor.

Modern management theories started after 1950s. Modern management theory focuses the development of each factor of workers and organization. Modern management theory refers to emphasizing the use of systematic mathematical techniques in the system with analyzing and understanding the inter-relationship of management and workers in all aspect.

\section{Quantitative Approach}

Quantitative approach also called Operation Research. Quantitative approach is a scientific method. It emphasizes the use of statistical model and systematic mathematical techniques to solving complex management problems. Its helps the management to making decisions in operations. It can only suggest the alternatives based on statistical data. It cannot take final decision.

It helps the management for improving their decision making by increasing the number of alternatives and giving faster decisions on any problem. Management can easily calculate the risk and benefit of various actions.

\section{System approach}

System approach was developed inlate1960s. Herbert A. Simon is the father of system theory. A System is defined as a set of regularly interacting or inter - dependent components that create as a whole unit. The system concept enables us to see the critical variables and constraints and their interactions with one another.

\section{Characteristics of system approach}

The Modern Period (1960 to present). After, 1960 management thought has been turning somewhat away from the extreme human relations ideas particularly regarding the direct relation between morale and productivity. Present management thinking wishes equal emphasis on man and machine.

The modern business ideologists have recognized the social responsibilities of business activities and thinking on similar lines. During the period, the principles of management reached a stage of refinement and perfection. The formation of big companies resulted in the separation of ownership and management. 
This change in ownership pattern inevitably brought in 'salaried and professional managers' in place of 'owner managers'. The giving of control to the hired management resulted in the wider use of scientific methods of management. But at the same time the professional management has become socially responsible to various sections of society such as customers, shareholders, suppliers, employees, trade unions and other Government agencies.

In the sphere of training managers Russian education demonstrates a high rate of development. However, teaching programs do not meet social needs on training specialists of this type. They mostly tend to superficially interpret western ideas and methods, without any deep analysis into the content of this educational sector, but with blind borrowing of pedagogical schemes and theoretical information which has very little in common with applied aspects of managerial activity. We can safely assume the necessity of training managers in accordance with new, perfected standards, which facilitate effective development of future managers' knowledge and skills. This will increase the efficiency of their performance, and, thus, will ensure the key ingredient of success on the level of a particular organization, economic sector, region, country and the human society on the whole (Osipova, 2018; Borisova et al., 2018; Borovikova, 2017; Larskikh \& Larina, 2017; Yazovskikh, 2018; Gadzaov \& Dzerzhinskaya, 2018; Gasanova et al., 2017; Gnatyuk \& Pekert, 2018; Kryuchkova, 2018; Kuznetsov et al., 2018).

The central thesis of this paper is that although some managers in different parts of the world could have achieved managerial success without having basic theoretical knowledge in management, it has to be unequivocally emphasized that those managers who have mixed management theory in their day-to-day practice, have had better chances of managing their organizations more efficiently and effectively to achieve both individual and organizational objectives. Therefore, managers of contemporary organizations ought to appreciate the important role they play in their respective organizations if they are to achieve set goals. Secondly, there is need to promote excellence among all persons in organizations, especially among managers themselves.

To address these concerns, the paper will proceed along the following spectrum: management will be defined for purposes of conceptual clarity; management objectives, functions, goals, and essentiality, will be highlighted; the importance of managerial skills and the organizational hierarchy will be sketched; the importance of women in the organizational hierarchy will be emphasized; reasons for studying management theory will be enumerated; the different management theories, the core of the paper, will be discussed at length; the significance of management as a practice will be contextualized; and 'the way forward' in form of a conclusion will be offered.

Definition of Management Management is the art, or science, of achieving goals through people. Since managers also supervise, management can be interpreted to mean literally "looking over" - i.e., making sure people do what they are supposed to do. Managers are, therefore, expected to ensure greater productivity or, using the current jargon, 'continuous improvement'.

More broadly, management is the process of designing and maintaining an environment in which individuals, working together in groups, efficiently accomplish selected aims (Koontz and Weihrich 1990, p. 4). In its expanded form, this basic definition means several things. First, as managers, people carry out the managerial functions of planning, organizing, staffing, leading, and controlling. Second, management applies to any kind of organization. Third, management applies to managers at all organizational levels. Fourth, the aim of all managers is the same - to create surplus. Finally, managing is concerned with productivity - this implies effectiveness and efficiency.

Thus, management refers to the development of bureaucracy that derives its importance from the need for strategic planning, co-ordination, directing and controlling of large and complex decision-making process. Essentially, therefore, management entails the acquisition of 
managerial competence, and effectiveness in the following key areas: problem solving, administration, human resource management, and organizational leadership.

First and foremost, management is about solving problems that keep emerging all the time in the course of an organization struggling to achieve its goals and objectives. Problem solving should be accompanied by problem identification, analysis and the implementation of remedies to managerial problems. Second, administration involves following laid down procedures (although procedures or rules should not be seen as ends in themselves) for the execution, control, communication, delegation and crisis management. Third, human resource management should be based on strategic integration of human resource, assessment of workers, and exchange of ideas between shareholders and workers. Finally, organizational leadership should be developed along lines of interpersonal relationship, teamwork, self-motivation to perform, emotional strength and maturity to handle situations, personal integrity, and general management skills.

\section{Management Functions}

To understand management, it is imperative that we break it down into five managerial functions, namely; planning, organizing, staffing, leading, and controlling.

Planning involves selecting missions and objectives and the actions to achieve them. It requires decision-making - i.e., choosing future courses of action from among alternatives. Plans range from overall purposes and objectives to the most detailed actions to be taken. No real plan exists until a decision - a commitment of human and material resources - has been made. In other words, before a decision is made, all that exists is planning study, analysis, or a proposal; there is no real plan.

People working together in groups to achieve some goal must have roles to play. Generally, these roles have to be defined and structured by someone who wants to make sure that people contribute in a specific way to group effort. Organizing, therefore, is that part of management that involves establishing an intentional structure of roles for people to fill in an organization. Intentional in that all tasks necessary to accomplish goals are assigned and assigned to people who can do them best. Indeed, the purpose of an organizational structure is to help in creating an environment for human performance. However, designing an organizational structure is not an easy managerial task because many problems are encountered in making structures fit situations, including both defining the kind of jobs that must be done and finding the people to do them.

Staffing involves filling, and keeping filled, the positions in the organization structure. This is done by identifying work-force requirements; inventorying the people available; and recruiting, selecting, placing, promoting, appraising, planning the careers of, compensating, and training or otherwise developing both candidates and current jobholders to accomplish their tasks effectively and efficiently.

Leading is the influencing of people so that they will contribute to organization and group goals; it has to do predominantly with the interpersonal aspect of managing. Most important problems to managers arise from people - their desires and attitudes, their behavior as individuals and in groups. Hence, effective managers need to be effective leaders. Leading involves motivation, leadership styles and approaches and communication.

Controlling, for example, budget for expense, is the measuring and correcting of activities of subordinates to ensure that events conform to plans. It measures performance against goals and plans, shows where negative deviations exist, and, by putting in motion actions to correct 
deviations, helps ensure accomplishment of plans. Although planning must precede controlling, plans are not self-achieving. Plans guide managers in the use of resources to accomplish specific goals; then activities are checked to determine whether they conform to the plans. Compelling events to conform to plans means locating the persons who are responsible for results that differ from planned action and then taking the necessary steps to improve performance. Thus, controlling what people do controls organizational outcomes.

\section{Literature Review}

To date there is a lot of pedagogical research connected with training effective specialists and, in particular, with developing a number of skills necessary to be accepted to a prestigious, decentlypaid job and to achieve excellent results within a chosen profession. The question of basic constituents of the manager's professional efficiency is given attention to in the works of O.S. Vikhanskiy, L.I. Korneeva, V.M. Shepel and others; the question of the manager's psychological development is covered by D. Goleman, R. Boyatzis, A. McKee and others; the perfection of intellectual and moral qualities of this profession representatives is described by H. Gregory, G.I. Ibragimova, G.V. Panasenko and others; N.A. Berdyaev, M.S. Kagan, E.R. Tagirov and others focus on particular aspects of the manager's professional activity; A.Y. Kibanov, G. Ford, F. Taylor write about a typical manager's character features and temperament; E.Y. Ayrapetyan, O.S. Vikhanskiy, A.M. Zobova and others concentrate on the content specifics of the manager's professional training. T.V. Alekseeva, L.S. Gavrilenko, I.O. Kotlyarova, E.N. Frantseva analyze the problems of differentiated innovative training (with regard to particular economic sectors). O.S. Gazman, O.M. Krasnoryadtseva, G.V. Mukhametzyanova, G.N. Serikov and others study students' preparedness for managerial activity in the new conditions.

Most scientists consider professional manager training to be a structured process of acquiring fundamental information, perfecting applied knowledge and skills which help a young specialist adapt to his/her professional responsibilities and work conditions as well as plan their own career progression in accordance with their goals and needs (Kan-Kalik, 1981).

The study of different scientific research dedicated to training competent managers allows making a conclusion about a lack of solid organizational and pedagogical technologies, methods and other factors which would facilitate successful development of the IEC in the process of training future managers within a higher educational institution.

\section{Proposed Methodology}

Professional manager training used to be carried out within the context of planned economy. But after the Soviet Union collapsed, the development of the economic sphere went along a completely different path, which required urgent changes in the system of manager training.

In Russian universities and higher education colleges, multifunctional managers are mainly trained following the model which is widely used in the USA, the country which takes leading positions in this educational sector and certifies MBA specialists (Master of Business Administration). This degree is worldwide recognized; it implies the ability to bear responsibilities at upper- and mid-level supervising positions. This very fact encouraged us to study the system of higher education in the USA, which can boast the most effective management infrastructure and the most positive experience of structured manager training.

The analysis of the basic aspects of the model used for training American managers (the conceptual, institutional, managerial and organizational-methodic aspects) led to the results, which, alongside with modern tendencies characterizing the process of training this type of specialists in the USA universities, allow, according to D.N. Sukhinenko, pointing out the specifics of the American system of training management specialists (Kolchina \& Sergeeva, 2017): 
- recognizing the significance of professional education for a successful activity of both an individual specialist and the whole company;

- in accordance with the concept of "the professional manager", which is the theoretical basis of the system of management and business education, the manager activity is an independent profession with its own specifications and high requirements to the level of specialist training;

- the priority interest of business schools in orders from individual customers and companies;

- training the professional manager comprises two equal constituents: the academic one (learning fundamental principles of management, the newest experience in the sphere of management, the tools of scientific analysis) and the practical one (applied skills of taking effective decisions, handling stress and conflict situations in the sphere of marketing, time management, etc.).

The study also allowed establishing the specifics of the Russian system of management education (Kolchina \& Sergeeva, 2016):

- the dominating role of the classic approach to higher education, which follows the German model with its knowledge pattern and priority of the government order in making educational programs; on the other hand, the requirements from the service users (university applicants, students and companies who need more management specialists) are ignored;

- Bachelor and Master degree curricula contain disciplines which do not match with the manager's future practical activity. This prevents the students from receiving the qualification which would allow them to realize their potential in the conditions of the market economy;

- the need in creating new patterns of the modern professional manager's activity considering the American education model and Russian traditions, with the aim of developing educational standards which are the most appropriate for the Russian conditions;

- developing Russian Master degree programs (similar to the MBA) as most dynamic, most demanded and targeted at the particular customer;

- the switch to a completely new level of manager training (the move from the concept "education for the whole life" to the concept "education through the whole life");

- transforming the management education into a key factor facilitating the formation and development of the specialist's professional career;

- practical usage of the technology of learning from reflective experience and activity, which brings together theoretical and applied knowledge, with the focus on professional reality, i.e. on what expects students after recruitment; the increased role of self-development work (group and individual) in the learning process;

- developing federal state educational standards of higher education supporting integration of specialties into wider complexes in order to create more exact frames;

- creating professional standards in accordance with the requirements of employers, i.e. individuals and companies who can determine norms and rules for the educational system which are aimed at training competitive specialists, wanted in the conditions of the market economy.

The analysis of the State Educational Standard of Higher Professional Education allows stating that the first standards were aimed to change the content side of the education. The education itself remained available and universal and provided students with the necessary minimum of information, whereas in the present-day standards the key component of education is its results, which are intended to match with the competence model of a university graduate. 
However, even though the entrepreneurial competence has been singled out in the State Educational Standard and referred to a separate group of professional competences which future managers have to acquire, it is not enough for the effective manager training.

Solving the problem of professional manager training in Russia, under the conditions of innovative economy, is only possible with the organization of the professional learning process on forming the future manager's innovative entrepreneurial competence, which we see as an individual integral qualitative professional characteristic including innovative entrepreneurial competences which form economically significant personal qualities (initiative, mobility, enterprise, independence in taking rational decisions, receptiveness to innovations) and reflect the readiness and ability to conduct professional activity in different spheres of economy through career progression, with the ability to notice new elements in the conditions of stability and make smart, perspective decisions in the situations of risk and uncertainty.

We interpret innovative entrepreneurial competences as a transparent system of knowledge and skills, as the experience of managerial activity and personal responsibility, which is realized and enriched in the context of the chosen profession on the background of particular managerial problems inevitable for a graduate specialist who tries his/her competences in practice.

The classifications presented in this paper refer to different criteria for distinguishing key professional competences, such as the scale of tasks (micro- and macrosocial); the dissemination level of competences (professional, managerial, corporative); the degree of development (differential or threshold); the content aspect (social, personal, cognitive, etc.). This allowed us to form the IEC structure of students, which consists of a number of innovative entrepreneurial competences (Stolyarenko, 2001):

basic, i.e. the key knowledge of economic-managerial character required for adaptation to the conditions of some particular activity in the context of market reality;

professional, i.e. the ability to use the above-mentioned knowledge in practice, to analyze untypical or not quite typical situations and make the choice leading to the most effective result with the lowest expenses;

extra, i.e. the ability to carry out managerial activity in a creative way, to successfully function on the labor market, to increase the level of professional education on a regular basis, etc.

Based on the conducted research, we designed a model of forming the IEC of future managers, which comprises interconnected clusters with regard to the activity goal, its content, the technologies used and the ways of assessing results.

The pedagogical factors which facilitate the formation of the IEC of future managers are determined by the essence and requirements of the last Federal State Educational Standards.

\section{Results}

Empirically proved criteria and indicators of the innovative entrepreneurial competence maturity of future managers are: axiological (the usage of the received innovative entrepreneurial knowledge in practice, in certain life situations; the aspiration and ability to solve professional tasks independently and creatively; understanding the necessity of developing the innovative entrepreneurial competence); cognitive (the knowledge of economic and management terms and notions, the ability to explain their meaning; the ability to properly analyze and infer cause-andeffect relationships within innovative entrepreneurial problems; the usage of knowledge for solving regular and untypical tasks); professionally significant qualities (the ability to make rational managerial decisions in situations of risk; professional vision, which is triggered in critical situations; the ability to handle conflict situations and stress factors); subjective (the level of self-esteem, the degree of criticism in the assessment of one's own activity results; confidence 
in success and self-efficacy; the ability to analyze one's own behavior in the case of conflict) and creative activity (the readiness for innovative entrepreneurial activity through digesting innovations; the ability to single out new elements in the normally running management process; the ability to look for the way out of difficult innovative entrepreneurial situations).

The technology of developing the innovative entrepreneurial competence of future managers implies the following stages:

the motivation-axiological stage aims to form the attitude to the future professional managerial activity as a personal and social value; understanding the significance of personal qualities necessary to be considered an economically competent specialist; the need in future professional and personal growth. At this stage, the emphasis is on the development of basic innovative entrepreneurial competences;

the cognitive activity stage suggests acquiring the corresponding volume of economic and management knowledge and skills as well as professional and managerial functions of the specialist; developing the abilities to solve management tasks with regards to innovative approach and creativity. At this stage, perfecting basic innovative entrepreneurial competences and developing professional innovative entrepreneurial competences become the focus of attention;

the refletive-modifying stage is focused on self-regulation of sensible managerial behavior and managerial activity; on the student's realization and evaluation of his/her own learning actions and professional managerial actions; on the actualization of economically significant personal qualities; on forming the ability to project their professional managerial development. At this stage, the formation of basic and professional innovative entrepreneurial competences is fully complete, while extra innovative entrepreneurial competences are being developed.

At the diagnostic stage of verification we measured the level of the innovative entrepreneurial competence of 54 future managers. The results showed mostly a low level of the innovative entrepreneurial competence. This determined the directions of increasing the effectiveness of the innovative entrepreneurial competence cultivation with the usage of the technology which we had developed.

The forming stage of the experiment involved 103 university students who were divided into four experimental and one control group:

- in the first experimental group (EG-1) we tested the first pedagogical condition, i.e. the introduction of the special course "Venture Entrepreneurship";

- in the second experimental group (EG-2) we tested the second pedagogical condition, i.e. the introduction of the complex of reflective pedagogical methods as an intensifying factor of the IEC development;

- in the third experimental group (EG-3) we tested the third pedagogical condition, i.e. the creation of motivational-axiological and emotional-stimulating background for developing the IEC of future managers;

- in the fourth experimental group (EG-4) we tested how the assembly of all the pedagogical conditions influenced the development of the IEC.

The control group (CG) was taught by means of traditional methods of the IEC development.

In the course of the forming stage of the experiment, interim results were received with regard to the criteria level of the components of students' innovative entrepreneurial competence in the experimental and control groups (Table 1). 
Table 1.

The criteria level of students' innovative entrepreneurial competence (the forming stage)

\begin{tabular}{|c|c|c|c|c|}
\hline \multirow[t]{3}{*}{ Criteria } & \multirow[t]{3}{*}{ Group } & \multicolumn{3}{|c|}{ Criteria levels of the components of the IEC } \\
\hline & & High & Medium & Low \\
\hline & & Students quantity, \% & Students quantity, \% & Students quantity, \% \\
\hline \multirow{2}{*}{$\begin{array}{l}\text { The motivation- } \\
\text { axiological }\end{array}$} & $\mathrm{CG}$ & 24,4 & 38,8 & 36,7 \\
\hline & EG & 33,3 & 52,6 & 14,1 \\
\hline \multirow[t]{2}{*}{ Cognitive } & $\mathrm{CG}$ & 18,3 & 42,8 & 38,8 \\
\hline & EG & 36,0 & 48,0 & 16,0 \\
\hline \multirow{2}{*}{$\begin{array}{l}\text { Professionally } \\
\text { significant qualities }\end{array}$} & CG & 30,6 & 49,0 & 20,4 \\
\hline & EG & 35,2 & 57,4 & 7,4 \\
\hline \multirow[t]{2}{*}{ Subjective } & $\mathrm{CG}$ & 26,5 & 46,9 & 26,5 \\
\hline & EG & 37,0 & 51,9 & 11,1 \\
\hline \multirow[t]{2}{*}{ Creative activity } & $\mathrm{CG}$ & 28,6 & 33,3 & 28,6 \\
\hline & EG & 38,9 & 50,0 & 11,1 \\
\hline
\end{tabular}

The results in Table 1 show that in all experimental groups the IEC levels generally increased in comparison with the control group. However, the quantity of students with low levels of the IEC development remains rather big (from 7.4 to 16\%). The cognitive criterion demonstrates the lowest result. Not all students are able to apply theoretical knowledge in practice successfully (Ksenzova, 2001).

The students demonstrated insufficiently developed skills of solving conflict situations as well as defining contradictions and developing case situations. They tend to make intuitional decisions at the expense of the technology of making alternative decisions. Future managers lack developed professional intentions, which are the connecting links with the innovative entrepreneurial competence of the management sphere specialists.

The analysis of the future managers' IEC development showed a significant difference in the quality of the innovative entrepreneurial competence development within its levels. In the course of further implementation of the created technology we need to minimize this difference at the forming stage of the experimental study.

\section{Conclusion}

Although the entrepreneurial competence has been singled out in the State Educational Standard into a separate group of professional competences which future managers have to acquire, it is not enough for the effective manager training. Solving the problem of the professional manager training in Russia, under the conditions of innovative economy, is only possible with the organization of the professional learning process on forming the future manager's innovative entrepreneurial competence, which we see as an individual integral qualitative professional characteristic including innovative entrepreneurial competences (basic, professional and extra). Based on the conducted research we designed a model of forming the IEC of future managers, which comprises interconnected clusters with regard to the activity goal, its content, the technologies used and the ways of assessing results. The criteria and indicators of the future managers' IEC level development (axiological, cognitive, professionally significant qualities, subjective, creative activity) allowed us to receive interim and control results, which were used to evaluate the efficiency of the pedagogical factors facilitating the IEC development. According to the interim results, the integration of several interconnected pedagogical conditions into the educational process results in higher efficiency; the control results demonstrate a positive dynamics in all experimental groups; the changes registered in the control group are insignificant. 
The verification of the process of the IEC formation proved the efficiency of the suggested technology and pedagogical factors facilitating the training of such managers who are oriented on the practical realization of their professional potential, meet the employers' requirements and are demanded on the labor market.

\section{References}

Ashmarov I.A. (2018). Some approaches to the study of the USSR' military economy in the soviet and russian national historiography. Historical Bulletin, 1(2), $19-31$.

Badakhova I.T. (2017). Formation of Professionally Significant Qualities of Future Managers in the Training Process Forming. Modern Scientist, 7, $81-84$.

Badakhova I.T. (2017). Formation of professionally significant qualities of future managers in the training process forming. Modern Scientist. 7, pp. $81-84$.

Borisova M.V., Musokhranov A.Yu., Sidorova N.A. (2018). Use of fitness directions elements on physical education classes and their psychomatic impact on students of the special medical group. Modern Scientist, 1, 6 - 9.

Borisova M.V., Musokhranov A.Yu., Sidorova N.A. (2018). Use of fitness directions elements on physical education classes and their psychomatic impact on students of the special medical group. Modern Scientist, 1, 6 - 9.

Borovikova T.V. (2017). Methodological bases of formation of the intellectual potential of territories in the conditions of innovative economy. Modern Economy Success, 6, 46 49.

Gadzaov A.F., Dzerzhinskaya M.R. (2018). Mathematical methods of analysis of the periodic components of economic processes. Modern Economy Success, 1, 14- 18.

Gadzhieva U.B. (2018). Socialization of personality as a factor in the mental, intellectual and spiritual-moral development. International Journal of Medicine and Psychology, 1(2), 17 -20 .

Gasanova P.G., Daudova D.M, Kabieva R.A., Tsahaeva A.A. (2017). Moral qualities of businessmen in public con-sciousness. Modern Scientist, 1(1), 209-211.

Gnatyuk S.N., Pekert N.A. (2018). Education as a factor of sustainable development of agriculture. Russian Economic Bulletin, 1(3), 18 - 27.

Kan-Kalik, V.A. (1981). Pedagogical activity as a creative process. PhD Thesis. Moscow: Scientific Research Institute of Higher Education Problems.

Kolchina, V.V., Sergeeva, M.G. (2016). Modelling the process of developing the innovative entrepreneurial competence of future managers. Scientific review: Humanitarian research. 9, 6-12.

Kolchina, V.V., Sergeeva, M.G. (2017). The realization of the complex of pedagogical conditions for the formation of the innovative entrepreneurial competence of future managers. Scientific review: Humanitarian research, 1, 28-34.

Komarova S.L. (2018). The assessment of the consumer basket for the analysis of the region competitiveness. Russian Economic Bulletin, 1(2), 19 - 25.

Kryuchkova K.S. (2018) Modular training of future teachers with the use of information technologies in the conditions of virtual academic mobility. Modern Humanities Success, 4, $9-14$.

Ksenzova, G.Y. (2001). Perspective school technologies. Moscow: Russia's Pedagogical Society.

Kuznetsov A.A., Ignatyeva T.A., Kuznetsov A.O. (2018). Strategy and key elements of competitiveness. Modern Economy Success, 1, 25 - 29.

Larskikh Z.P., Larina I.B. (2017). Holding an elective course with the purpose of formation communicative culture of a future bachelor. Modern Scientist, 6, $168-171$.

Narkevich L.V. (2018). Analysis of industrial capacity and break-even production in the crisis management system. Russian Economic Bulletin, 1(3), 28 - 41.

Osipova M.B. (2018). Tendencies of development of educational practice of the modern educational organizations. Modern Humanities Success, 1, 10 - 13. 
Schwarzkopf N.V. (2018). Improving the use of data mining technology as a way of reducing credit risk. Russian Economic Bulletin, 1(1), 10 - 18.

Sergeeva M.G., Trubakova D.I. (2017). Teacher's Reflection Formation as Factor of Effectiveness Children's Social Intelligence Forming. Modern Scientist, 7, 62 - 64.

Stolyarenko, A.M. (2001). Psychology and Pedagogy. Moscow: UNITY-DANA.

Yazovskikh E.V. (2018). Employment of graduates as one of the efficient activity indicators of the higher educational establishment, ural federal university is taken as an example processes. Modern Economy Success, 1, 33 - 37. 